\title{
Nutrition and the Aorto-Iliac Atherosclerotic Disease
}

\author{
Sergio Santana Porbén \\ Nutritional Support Group, "Hermanos Ameijeiras" Clinical surgical Hospital, \\ La Habana, \\ Cuba
}

\section{Introduction}

ESRV Elective Surgical Revascularization is the ultimate intervention in atherosclerotic aorto-iliac disease which has progressed up to the arterial insufficiency state [1]. Surgical solution of extreme forms of aorto-iliac atherosclerotic disease (such as aortic aneurysm) implies removal of the stenotic/dilated arterial segment, creation of an arterial derivation, and/or placement of a vascular prosthesis [2]. Surgical act entails a metabolic aggression whose cost might override the patient's homeostatic mechanisms, resulting in complications and death [3-4]. Consequently, the medical team should care for the safe completion of the surgical procedure through identification and proactive modification of factors existing in the patient that might place him/her at risk of complication and death.

Patient's nutritional status can determine the result of surgical activity. An increased risk of surgical failures has been reported as patient's nutritional status deteriorates [5-7]. However, relationship between the response to the surgical act and nutritional status might not be that straightforward, and could be modified by fuzzy variables such as age and presence of comorbidities [8-9].

The present essay gives the opportunity for assessing the relationship between nutritional status of the patient and surgical activity from a different, entirely new, perspective. That is: it would be interesting to examine if body weight excess can also modify the results of surgical activity non-related to tumor-reduction, as would be the case of ESRV. This study model of systemic response to surgical aggression could be more appealing in view of the fact that abnormalities of the great abdominal vessels intended to be surgically corrected represent different stations in the progression of atherosclerotic disease, and this, in turn, is associated with Obesity. Thus, it could be anticipated that surgical failures rate to increase as patient's body fat does.

\section{Atherosclerosis and nutrition}

Any discussion on the possible links between atherosclerotic aorto-iliac disease and nutrition should take into account the influence of subject's food habits upon onset and history (in absence of intervention) of this illness, the nutritional status of the patient prior to ESRV, and nutritional influence upon the response to the surgical act.

Atherosclerosis is intimately related with disorders of blood lipids homeostasis [10-11]. Although fat strip has been described as the originary atherosclerotic lesion in the aorta of 
newborn babies, its conversion into an atheroma, with subsequent calcification, rupture and thrombosis, or weakening of the arterial wall, are all associated with chronic states of hypercholesterolemia [11-12]. However, it should be noticed that causes of hypercholesterolemia can be multiple and chaotic in their presentation and influences [13]. Obesity, established from the disproportionate participation, and anomalous distribution, of body fat in the subject's body composition, and the repercussion that specified topographical locations of adipose tissue have upon endocrine activity of human economy as well as cell and tissue metabolism, is an important factor in the progression of atherosclerotic damage [14-15]. Obesity results from the incapacity of the organism to correctly use food energy quantities incongruent with subject's physical activity, in particular if present in his/her regular diet as refined sugars and energetically dense foods. Coincidently, elevated food fats intakes, with an important participation of saturated fats and trans fatty acids, have been described in obese subjects [15-18]. Hypercholesterolemia could also be the result of unbalanced intakes of long-chain, poly-unsaturated fatty acids, and poor representation of $\omega 3$ fatty acids in the diet $[13,19]$. All these food influences converge to configure the so-called Metabolic syndrome, which eventually leads to hyperuricemia, blood lipids disorders, and disruption of the peripheral utilization of carbohydrates, that might evolve towards hyperglycemia and insulin resistance; molecular events all that accelerate the progression of atherosclerotic disease [20-21].

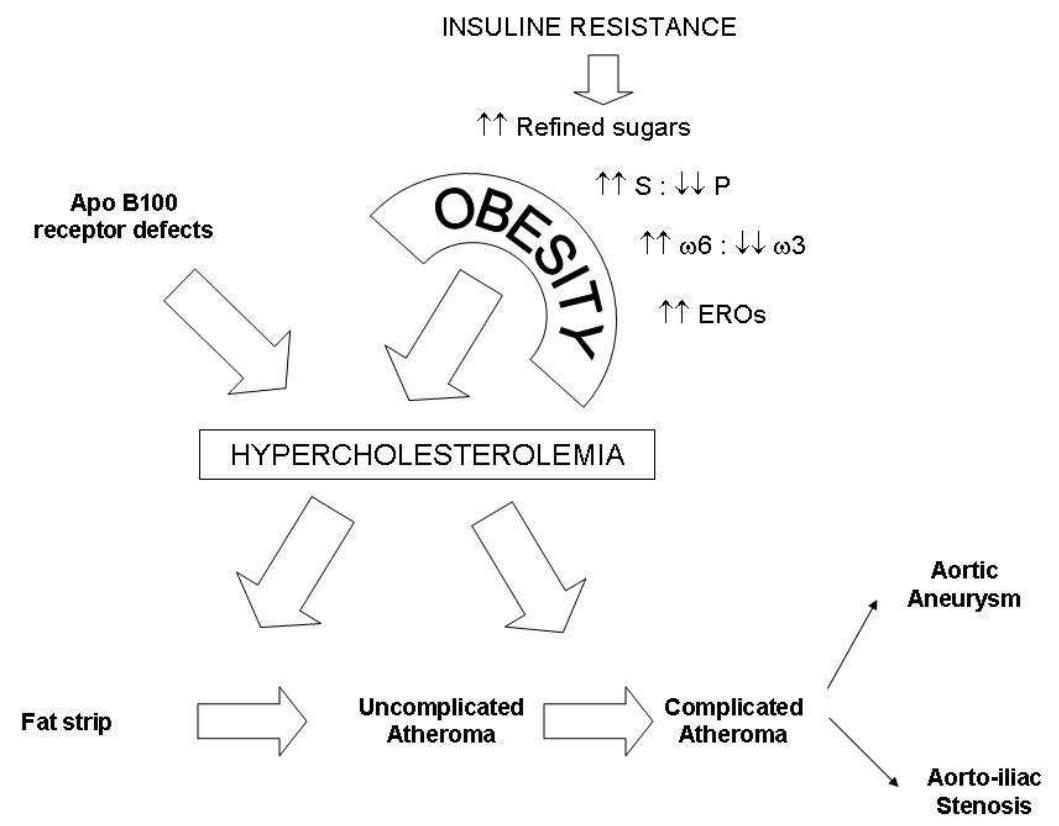

Legends: S: Saturated fats. P: Poly-unsaturated fats. ORSs: Oxygen-reactive species

Fig. 1. Some influences in the progression of the originary atherosclerotic lesion. The figure intends to call the attention upon factors involved in atherosclerosis dependant on Obesity as well as molecular defects in LDL-Cholesterol clearance. The presentation does not exhaust the events related with atherosclerosis, nor the relationships they sustain among them. For further details: See pertinent references at the end of the essay. 


\section{Nutritional phenotypes in atherosclerotic aorto-iliac disease}

Corresponding with what has been said previously, it should not come as a surprise to see that a significant proportion of aorto-sclerosis patients considered for ESRV show a body weight higher that the one expected regarding the height of their peers, as seen in Figure 2 . Regarding BMI Body Mass Index, 69 patients assisted between 2000 - 2007 due to aorto-iliac atherosclerosis (more than half presenting with aortic aneurysm) at a Angiology and Vascular surgery of a referral, tertiary hospital of the city of Havana (Cuba) were distributed as follows: Malnourished: < $18.5 \mathrm{Kg} \cdot \mathrm{m}^{-2}$ : 4.3\%; Non-Malnourished: Between 18.5 - 24.9 Kg.m-2: 41.4\%; and Body weight excess: > 24.9 Kg.m-2: $54.3 \%$; respectively. Fourteen point 2 percent of the patients was obese on admission to the Service.

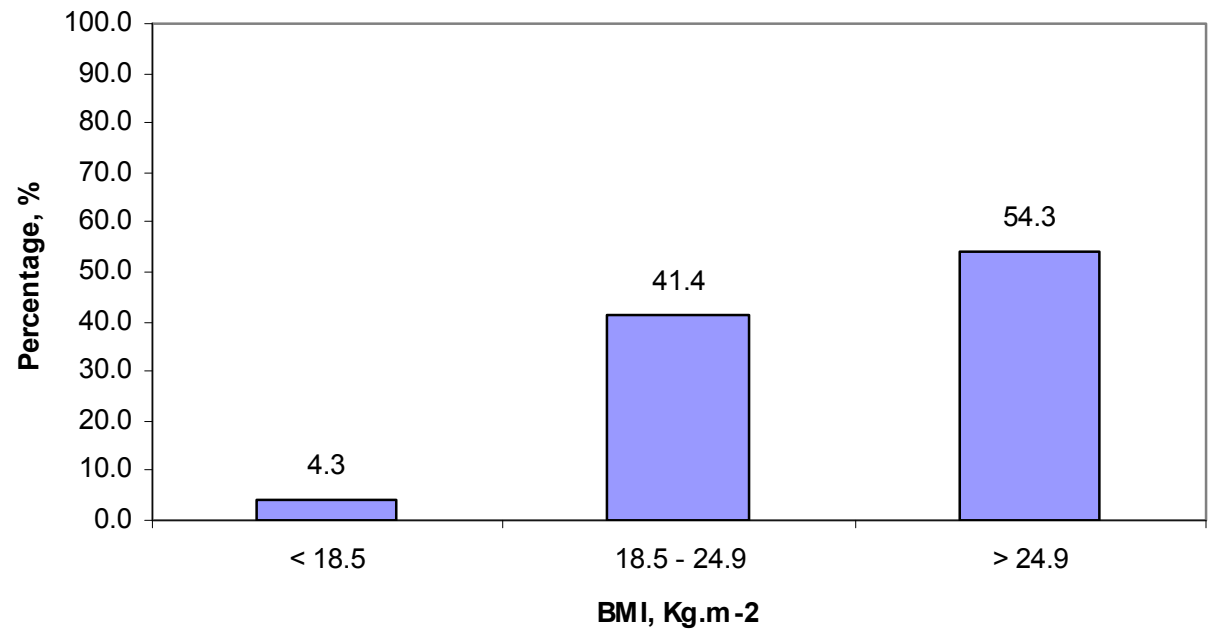

Legend: BMI: Body Mass Index.

Source: Records of the Nutritional Support Group. Clinical surgical Hospital "Hermanos Ameijeiras".

La Habana. Cuba.

Records closed on: Monday, October 10th, 2010.

Fig. 2. Distribution of different nutritional phenotypes among patients awaiting elective surgical revascularization in a referral, tertiary, Angiology service. More than half of patients presented with aortic aneurysm.

Having reached this point in the essay, a relevant question is pertinent: Can body weight excess (in either of its two forms: overweight or obesity) affect the response to ESRV? In other words: does the risk of complications after ESRV increase because of size/distribution of body fat? If this is to be the case, patient's response to ESRV could be improved, and in the process, a higher-quality medical-surgical care offered, by means of the conduction of proactive measures oriented to modify the size as well as topographical distribution of body fat.

The relevance of these considerations is not to be ignored. ESRV includes technicallydemanding procedures, such as aorto-femoral derivation, and placement of vascular prostheses. Complications that might occur after completion of such procedures can encompass from sepsis to derivation/prosthesis failure, with subsequent amputation of the 
vascular compromised limb [3-4,22]. Interestingly, considerations about the association between surgical activity and nutritional status have been dominated by the discussion on how weight loss affects the result of surgical tumor-reduction [5-8]. On the contrary, documented evidences on the influence of body weight excess upon the response of the patient to surgical activity non-related with oncology practice are scarce. However, it has been hypothesized that the relationship between risk of complication after a surgical act and nutritional status of the patient might adopt a " $U$ " or "J" shape, as shown in Figure 3 [2324]. The shape of this relationship is striking, because it stresses that polar nutritional phenotypes can be equivalent in their influences upon the response of the patient to the surgical activity 1 .

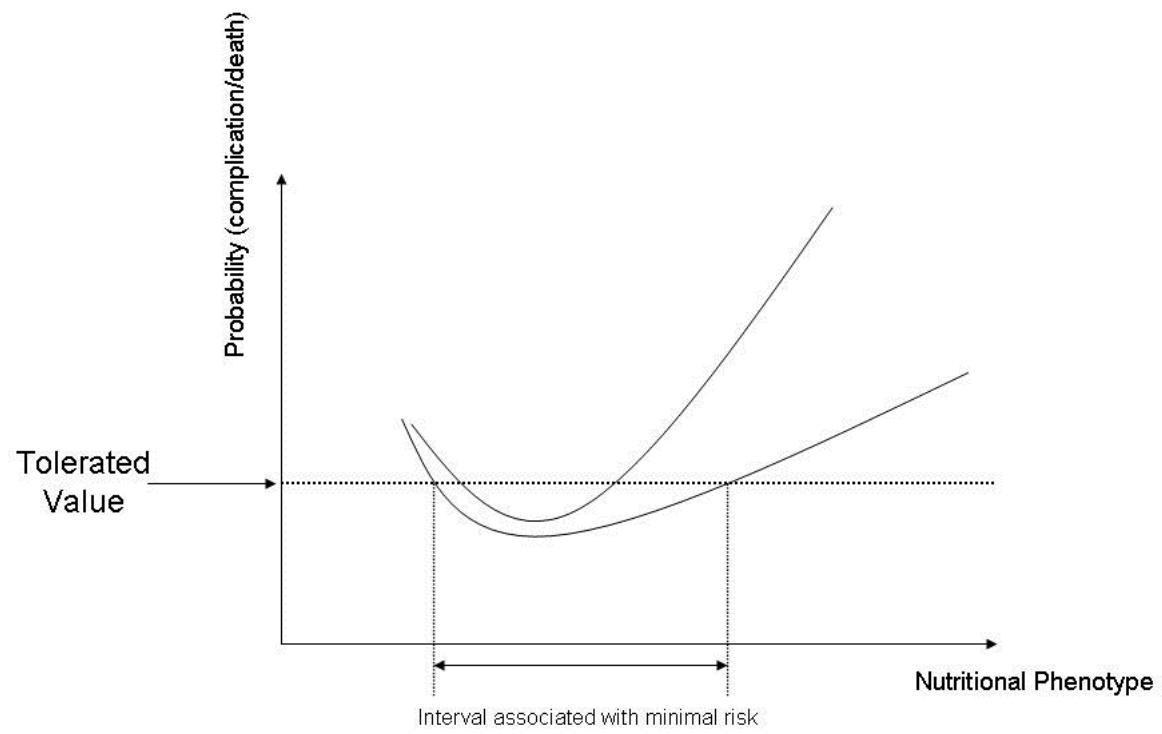

WEIGHT LOSS ACCEPTABLE WEIGHT BODY WEIGHT EXCESS

Drawn with data taken from: References [23-24].

Fig. 3. Influence of nutritional phenotype upon response to the surgical act.

\section{Why polar nutritional phenotypes are equally deleterious for the response to ESRV?}

ENM Energy Nutrient Malnutrition is that disorder of body composition resulting from depletion of Potassium-rich, metabolic-active, lean tissues [26]. Reduction of body lean mass beyond a critical size is associated with an increased risk of complications after ESRV, not to

\footnotetext{
${ }^{1}$ Unfortunately, the author has not been able to validate this hypothesis. After research completed in a Angiology and Vascular Surgery referral, tertiary Service, it was concluded that post-surgical complications were independent from nutritional phenotype, affecting two-thirds of non-malnourished patients, and half plus one of those with body weight excess [25].
} 
mention death ${ }^{2}$. ENM deeply affects all the orders of subject's economy, and profoundly alters inner milieu homeostasis. Malnutrition usually associates with impaired liver protein synthesis and tissue repair and healing processes, and defective collagen deposition, thus difficulting the formation of an effective scar callous [24, 27]. Malnutrition also brings about disruption of the natural barriers for restraining invading pathogen bacteria, antigenpresentation mechanisms, production and release of cytokines, immunoglobulins and cell mobilization factors, and the proliferation and differentiation of cells involved in immune response [28]. Far from exhausting the topic, malnutrition can affect ventilatory function, making the subject prone to failure in weaning from a mechanical ventilator and pneumonia [29]; as well as kidney function, thus altering depuration of toxins and other by-products of tissue metabolism [30].

By comparison, influence of body weight excess upon response to surgical activity has been little explored, above all in settings non-related with tumor-reduction. Excess of subcutaneous adipose tissue can result in an increased rate of surgical wound sepsis due to failure in obliterating the incision line, and subsequent appearance of dead spaces. Poor vascularity of subcutaneous adipose tissue can also contribute to an insufficient irrigation of surgically lacerated tissues, and thus, inflammation, bacterial colonization, and surgical wound sepsis. Suture dehiscence, incisional hernias and eventrations could then become the most visible face of the influence of body weight excess upon surgical activity.

But body weight excess can also exert remote influences through altered states of peripheral utilization of carbohydrates. Indeed, hyperglycemia has been described as a post-surgical sepsis risk factor [31]. It is to be kept in mind that cells involved in immune response are important consumers of energy as glucose [32]. Hyperglycemia can result from disorders in the peripheral utilization of carbohydrates as well as hyper-insulinism states. Insulin action target-cell can express a reduced number of hormone-specific receptors, or uncouple the receptor from post-receptor cascade of events, inhibiting in one way or the other stimulation by insulin, a phenomenon recognized as "down-regulation". Incapacity of using glucose as the energy substrate of choice forces the cell to turn to alternative energy fuels, which in the end, worsens hypertrigliceridemia resulting from improper cell utilization of metabolic energy.

Body weight excess can be also associated with chronic states of inflammation. Depending on the topographical location, the adipocyte is able to produce cytokines ( $\alpha$ TNF Tissue Necrosis Factor among them), and other inflammation-promoting molecules [33]. These blood products also contribute to insulin resistance, hyperglycemia and hypertrigliceridemia. Hence, and given what has been said before, body weight excess can become a powerful negative predictor of complications after ESRV.

\section{Can age independently influence upon response to ESRV?}

Relationship between probability of complication after ESRV and nutritional phenotype has been documented in subjects younger than 60 years of age [23, 24]. However, such dependence relationship has not been established in older subjects. As a matter of fact, it has come to the attention of researchers that body weight excess is associated with a lesser risk of complications after completion of surgical acts non-related with tumor-reduction in

\footnotetext{
2 There is also depletion of adipose tissue in ENM, but this phenomenon is secondary to the reduction of the size of body lean mass. As a matter of fact, post-surgical complications can occur in a patient with a nearly constant adipose tissue.
} 
elderly subjects [34]. In a recently concluded research at a referral, terminal Angiology Service, it was observed that age was an independent predictor of after-ESRV failures when higher complications rates concentrated among younger subjects notwithstanding nutritional phenotype [25]. Hence, it is only attractive to explore why age transit can cause such a profound transformation of the relationship discussed throughout this essay.

Significant changes occur in subject's body composition with aging. These changes could result from "turning off" molecular signals responsible for tissue accretion (explaining, at least in part, the phenomenon of "sarcopenia"); redistribution of body compartments, with preponderance of adipose tissue deposition at the scapular waist, and concomitant reduction of the circumference of body segments and/or substitution of body lean mass with adipose tissue [35]. These changes could, in turn, modify subject's hormonal status, reducing insulin resistance, and thus, altered states of peripheral utilization of carbohydrates [36]. The morpho-functional substrate such as the one early described might then explain why Obesity, understood as an increase in body fat size, can act as a protecting factor in the third age of life. Hence, others events/circumstances aside, a subject with +60 years of age could tolerate ESRV better if he/she presents to the surgical act with body weight excess, when compared with younger peers.

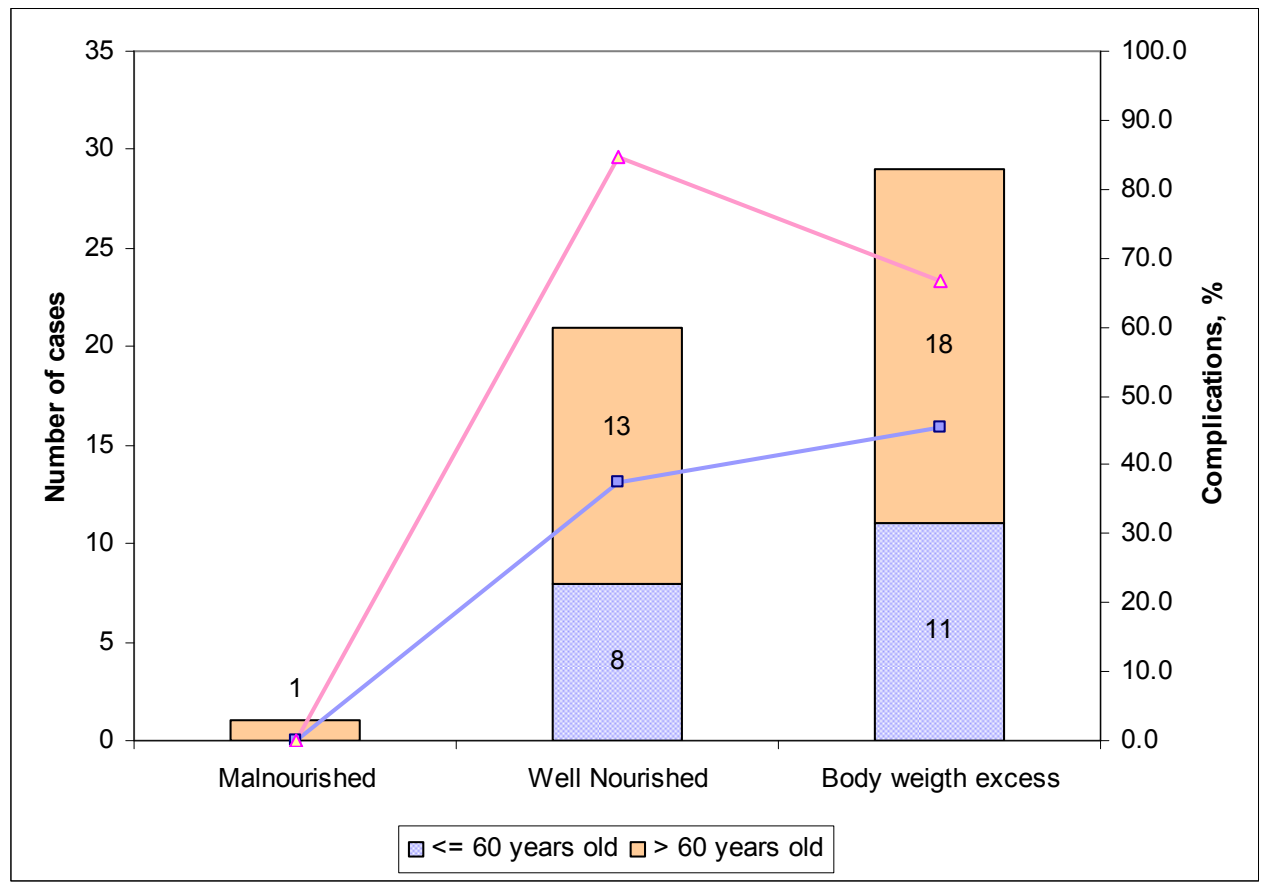

Reproduced from: Reference [25] with the authorization of the Editorial board of ANGIOLOGIA, bimonthly journal of the Spanish Society of Angiology and Vascular Surgery.

Fig. 4. Complications observed after completion of ESRV in a referral, terminal Angiology Service. Cases are distributed according with nutritional status and age. Blue solid line: Complications observed in subjects younger than 60 years. Pink solid line: Complications observed in elder subjects. More than half of patients presented with aortic aneurysm. 


\section{On perioperatory nutritional intervention in ESRV}

Having discussed the aforementioned issues, it is time to dwell about interventions oriented to secure the success of ESRV by supplying the patient with selected nutrients incorporating intrinsic pharmacological actions, such as $\omega 3$ fatty acids and dietetic fiber.

Pharmacological actions of $\omega 3$ fatty acids have been intensively studied in recent years. $\omega 3$ fatty acids, brought by oily seeds and deep waters fishes, might act as precursors of 3- and

\begin{tabular}{|c|c|c|c|c|}
\hline Nutrient & $\begin{array}{l}\text { Recommended } \\
\text { intake }\end{array}$ & Foods & $\begin{array}{c}\text { Enteral } \\
\text { Nutrients }\end{array}$ & $\begin{array}{l}\text { Parenteral } \\
\text { Nutrients }\end{array}$ \\
\hline $\begin{array}{l}\omega 3 \text { fatty acids } \\
\text { - DHA }\end{array}$ & $200 \mathrm{mg} .24 \mathrm{~h}-1$ & $\begin{array}{c}\text { Flaxseed oil } \\
\text { Deep water fishes: } \\
\text { herring, cod }\end{array}$ & $\begin{array}{c}\text { SUPPORTAN } \omega 3 \\
\text { (Fresenius-Kabi, Germany) } \\
\text { NUTRICOMP IMMUN } \\
\text { (BBRAUN, Germany) } \\
\text { NUTRICOMP Diabetes } \\
\text { (BBRAUN, Germany) }\end{array}$ & $\begin{array}{c}\text { LIPOPLUS (BBRAUN, } \\
\text { Germany) } \\
\text { STRUCTOLIPIDS } \\
\text { (Fresenius-Kabi, } \\
\text { Germany) }\end{array}$ \\
\hline $\begin{array}{l}\omega 3 \text { fatty acids } \\
\text { - DPA }\end{array}$ & $\begin{array}{l}\text { Not } \\
\text { established }\end{array}$ & $\begin{array}{l}\text { Flaxseed oil } \\
\text { Deep water fishes: } \\
\text { herring, cod }\end{array}$ & $\begin{array}{c}\text { SUPPORTAN } \omega 3 \\
\text { (Fresenius-Kabi, Germany) } \\
\text { NUTRICOMP IMMUN } \\
\text { (BBRAUN, Germany) } \\
\text { NUTRICOMP Diabetes } \\
\text { (BBRAUN, Germany) }\end{array}$ & $\begin{array}{c}\text { LIPOPLUS (BBRAUN, } \\
\text { Germany) } \\
\text { STRUCTOLIPIDS } \\
\text { (Fresenius-Kabi, } \\
\text { Germany) }\end{array}$ \\
\hline $\begin{array}{l}\omega 3 \text { fatty acids } \\
\text { - EPA }\end{array}$ & 200 mg.24 h-1 & $\begin{array}{c}\text { Flaxseed oil } \\
\text { Deep water fishes: } \\
\text { herring, cod }\end{array}$ & $\begin{array}{c}\text { SUPPORTAN } \omega 3 \\
\text { (Fresenius-Kabi, Germany) } \\
\text { NUTRICOMP IMMUN } \\
\text { (BBRAUN, Germany) } \\
\text { NUTRICOMP Diabetes } \\
\text { (BBRAUN, Germany) }\end{array}$ & $\begin{array}{c}\text { LIPOPLUS (BBRAUN, } \\
\text { Germany) } \\
\text { STRUCTOLIPIDS } \\
\text { (Fresenius-Kabi, } \\
\text { Germany) }\end{array}$ \\
\hline $\begin{array}{l}\text { Dietetic fiber } \\
\text { - Soluble }\end{array}$ & $10-15 \mathrm{~g} /$ day & $\begin{array}{c}\text { Fruits, beans, } \\
\text { selected vegetables }\end{array}$ & $\begin{array}{c}\text { NUTRICOMP Diabetes } \\
\text { (BBRAUN, Germany) }\end{array}$ & Non available \\
\hline $\begin{array}{l}\text { Dietetic fiber } \\
\text { - Non-soluble }\end{array}$ & $10-15 \mathrm{~g} /$ day & $\begin{array}{c}\text { Non-digested parts } \\
\text { of fruits, beans, } \\
\text { vegetables }\end{array}$ & $\begin{array}{c}\text { NUTRICOMP Standard } \\
\text { w/ Fibre (BBRAUN, } \\
\text { Germany): } \\
7.5 \mathrm{~g} / 500 \mathrm{~mL}\end{array}$ & Non available \\
\hline Glycerol & $\begin{array}{c}\text { Not } \\
\text { established }\end{array}$ & $\begin{array}{l}\text { Lards, butter, } \\
\text { margarines }\end{array}$ & Non available & $\begin{array}{c}\text { LIPOFUNDIN } \\
\text { LCT/MCT (BBRAUN, } \\
\text { Germany): } \\
25 \mathrm{~g} / 1000 \mathrm{~mL} \\
\text { LIPOPLUS (BBRAUN, } \\
\text { Germany): } \\
25 \mathrm{~g} / 1000 \mathrm{~mL} \\
\text { ProcalAmine } \\
\text { (BBRAUN, Germany): } \\
25 \mathrm{~g} / 1000 \mathrm{~mL}\end{array}$ \\
\hline
\end{tabular}

Legend: DHA: Docosahexanoic acid. DPA: Docosapentanoic acid. EP: Eicosapentanoic acid. Note: Soluble, dietetic fiber refers to mucins and pectins. Insoluble, dietetic fiber refers to cellulose and hemi-cellulose.

Table 1. Nutrients known for their effect upon insulin resistance and peripheral utilization of sugars. It is not intended to be a comprehensive list of presented items. 
5-series prostanoids, with documented anti-inflammatory, anti-clotting, and smooth musclerelaxing properties [37]. Supply of such fatty acids, be either as foods or chemically defined preparations, could then become an intervention resulting in a lesser systemic inflammatory activity, and thus, a better utilization of cell as well as tissue energy substrates [38]. Use of $\omega 3$ fatty acids as part of nutritional intervention in ESRV might also result in stabilization of the atherosclerotic plaque, thus facilitating the work of angiologist surgeon [39]. Morever, it has been reported that use of parenteral lipids solutions incorporating fish oil as a source of $\omega 3$ fatty acids shortened hospital length of stay of patients electively subjected to abdominal aortic aneurysm surgery [40]. However, is should be remembered that prolonged use of $\omega 3$ fatty acids might modify shape, size, distribution and lipid composition of HDL High density Lipoproteins that have been linked to a reduced risk of atherosclerotic damage [41].

Dietetic fiber could be another nutrient capable to influence upon response to ESRV. Low dietetic fiber intakes have been described after surveys completed in obese subjects [42-43]. Low dietetic fiber intakes have been associated with occurrence of blood lipid disorders and increased peripheral resistance to insulin action [44]. Supply of dietetic fiber might improve cell/tissue response to insulin's stimulatory action, and hence, altered states of carbohydrates peripheral utilization [45]. Likewise, dietetic fiber might also modify features and distribution of plasma lipoproteins in charge of Cholesterol and triglycerides transportation [46].

Finally, being hyperglycemia the first complication associated with/derived from body weight excess upon which to intervene after ESRV, alternative sugars solutions to Glucose should be made available to the angiologist surgeon for energy supply to the patient. Several alternative sugars have been proposed, such as xylitol, glucitol and sorbitol [47]. Glycerol: the poly-alcohol supplying the carbon backbone sustaining triglycerides's structure, has also been proposed as an alternative substrate to Glucose in post-surgical settings where insulin resistance, hyperglycemia, and hypertrygliceridemia are to be expected [48].

\section{Clinical case: Ischemia-reperfusion syndrome - Influence upon nutritional status and response to ESRV}

Complicated atherosclerosis is associated with a reduced blood irrigation of regions distal to atherosclerotic lesion, and hence, chronic tissue ischemia. When blood supply is restored after ESRV, molecular signals generated by until-that-moment ischemic tissues enter the blood stream. Systemic influence of such molecular signals might simulate the shock picture firstly described in people trapped in collapses [49]. Ischemia-reperfusion syndrome thus configured might affect nutritional status of patient subjected to ESRV, and complicate the implementation of designed nutritional support scheme.

Case presentation: The case is presented of a 55 years-old, white female, being admitted to a referral, terminal Angiology and Vascular Surgery Service for surgical correction of a mesenteric-aorto-iliac atheromatosis. The list with health problems identified in this patient is displayed in Table 2. During the surgical act, an aorto-iliac derivation was made, along with reopening of the superior mesenteric artery and placement of a bypass. Post-surgical evolution was torpid, marked by a Multiple Organs Dysfunction event, local as well as systematic sepsis, and a SIRS Systemic Inflammatory Response System. Health problems presented during post-operatory follow-up were all medically treated. Eventually the patient overcome these problems and was discharged from the Service. 
Pr 1. Chronic tobacco use.

Pr 2. Complicated mesenteric-aorto-iliac Atherosclerosis.

Pr 3. Moderate Energy Nutrient Malnutrition of the Marasmatic type.

sPr 3.1 Sixteen Kg weight loss during the last 6 months.

- Volitional enteral Nutrition: Generic, fiberless, polimeric diet: $400 \mathrm{Kcal} .24 \mathrm{~h}-1$

H1: Mesenteric insufficiency.

- Jejunum biopsy: No villous atrophy is observed. Mild congestion of lymph and blood vessels.

Pr 4. Peripheral arterial insufficiency.

sPr 4.1 Intermittent claudication.

- Oriented pharmacological treatment.

- Laparotomy.

- Aortic endarteriectomy.

- Placement of an end-to-end aortic prosthesis.

- Aorto-iliac bypass.

- Superior mesenteric-aortic bypass.

Pr 5. Complicated Endarteriectomy Post-operatory Status.

sPr 5.1 Systemic sepsis: Bacterial bronchopneumonia.

- ATB: Cefotaxime+Gentamicine

sPr 5.2 Local sepsis: Moniliasic glosytis

- Nistatine mouth washes.

Pr 6. Multiple Organ Disfunction

sPr 6.1 Small bowel dysfunction: Diarrheas.

- $\quad$ Nils per Oris

- Central Parenteral Nutrition: Dextrose 10\%: 800 Kcal.24 h-1 + Aminoacids 10\%: 50 g.24 h-1

sPr 6.2 Lung dysfunction: Lung congestion.

sPr 6.3 Liver dysfunction: Prolonged coagulogram.

- K Vitamin administration.

sPr 6.4 Heart dysfunction: Acute heart insufficiency.

- Treatment w/ Digitalics.

- Heart function support w/ Amines

sPr 6.5 Bone marrow dysfunction: Anemia

- Blood transfusion: Two 500 mL-bags of blood.

Pr 7. SIRS Systemic Inflammatory Response Syndrome.

sPr 7.1 Hydroelectrolitic disorders.

sPr 7.2 Upper digestive bleeding.

$\mathrm{H} 2$ : Stress ulcers

- $\quad$ Nils per Oris

- Interruption of Central Parenteral Nutrition scheme.

Table 2. Patient's health problems listing.

Table 3 shows the evolution of selected nutritional as well as welfare markers collected during the patient's treatment window. Weight loss accentuated during post-operatory evolution, as expression of existing tissue catabolism. Haemoglobin values never went beyond the 120 g.L-1 limit. Observed anemia might compound several causes, among them, 
insufficient supply of nutrients. A marked lymphopenia was observed, as expression of the immune suppression accompanying SIRS installed during post-operatory evolution. Serum Cholesterol values were lower than $3.5 \mathrm{mmol} . \mathrm{L}^{-1}$, confirming inflammatory status present in the patient as response to the ischemia-reperfusion syndrome. Interestingly, depletion of serum Albumin values was not observed, pointing to a liver function preserved enough to sustain nitrogen anabolism. This circumstance might explain the patient's favorable evolution, in spite of recorded events. There was also constancy of serum Creatinine values, indicating a conserved depurative kidney function for securing inner milieu homeostasis.

\begin{tabular}{|c|c|c|c|c|c|c|c|}
\hline $\begin{array}{c}\text { Day of } \\
\text { Evolution }\end{array}$ & $\begin{array}{c}\text { Weight, } \\
\mathrm{Kg}\end{array}$ & $\begin{array}{c}\mathrm{MAC}, \\
\mathrm{Cm}\end{array}$ & $\begin{array}{l}\mathrm{Hb}, \\
\text { g.L-1 }\end{array}$ & $\begin{array}{c}\text { TLC, } \\
\text { cél.mm3 }\end{array}$ & $\begin{array}{c}\text { S-Cre, } \\
\text { umol.L-1 }\end{array}$ & $\begin{array}{l}\text { S-Alb, } \\
\text { g.L-1 }\end{array}$ & $\begin{array}{c}\text { S-Chol, } \\
\text { mmol.L-1 }\end{array}$ \\
\hline-58 & 36.0 & & 102 & 2478 & 59.7 & 40.0 & \\
\hline-26 & 35.0 & & & & & & \\
\hline-15 & & & 117 & & 61.0 & 44.0 & 3.9 \\
\hline-12 & 33.0 & 20.3 & & & & & \\
\hline-3 & 35.0 & 20.0 & & & & & \\
\hline-1 & & & 105 & & & & \\
\hline 0 & & & 90 & & & & \\
\hline+2 & & & 111 & & 67.6 & & \\
\hline+3 & 37.0 & 21.0 & 141 & 1782 & & & \\
\hline+4 & & & 157 & 1496 & 53.0 & 32.5 & \\
\hline+9 & 40.0 & & & & & & \\
\hline+11 & & & 75 & & 46.6 & & \\
\hline+12 & 40.0 & 20.0 & & & & & \\
\hline+13 & & & 75 & 1188 & & & \\
\hline+14 & & & & & 41.0 & & \\
\hline+17 & & & 92 & 888 & 67.0 & & \\
\hline+19 & & & 99 & & 52.0 & & 3.1 \\
\hline+22 & & & 54 & 459 & & & \\
\hline+24 & & & 105 & & & & \\
\hline+30 & & & & 1320 & 56.0 & & \\
\hline+37 & 32.0 & 17.0 & 116 & & & & \\
\hline+44 & & & 109 & 3960 & 67.6 & 38.0 & 4.7 \\
\hline+132 & 41.0 & & & & & & \\
\hline+151 & & & 108 & & 91.3 & & 4.5 \\
\hline
\end{tabular}

Legend: MAC: Mid-arm-circumference. Hb: Hemoglobin. TLC: Total Lympochytes Count. S-Cre: Serum Creatinine. S-Alb: Serum Albumin. S-Chol: Serum Cholesterol.

Table 3. Behavior of selected nutritional as well as welfare markers of the patient discussed in the "Clinical case presentation" section. Shaded boxes indicate abnormal values of the corresponding marker. See text for further details. 
Hemodynamic instability situation experienced by the patient during post-operatory course prevented the installment of coherent nutritional support schemes. This can be better appreciated in Figure 5. Important discontinuities in the use of the oral route for sustaining nutritional status were observed during the 20 days following the surgical act. Bowel insufficiency warned against the use of enteral nutrients during this stage as a substitute for oral feedings. In spite of all these events, the hospital NST Nutritional Support Team always stood for timely rehabilitation of the oral route, and prescribed the supply of energy as lowdensity Dextrose solutions. A hyperglycemia event (serum Glucose: 22.1 mmol.L-1) was identified on day +13 of post-surgical evolution, forcing to momentarily interrupt the infusion of Dextrose solutions. Eventually, once hemodynamic stability was achieved, organic function recovered, and sepsis foci controlled, oral route was used for satisfying patient's nutrients needs. This action, along with parenteral aminoacids supplementation, might have been determinant in patient's response to ESRV.

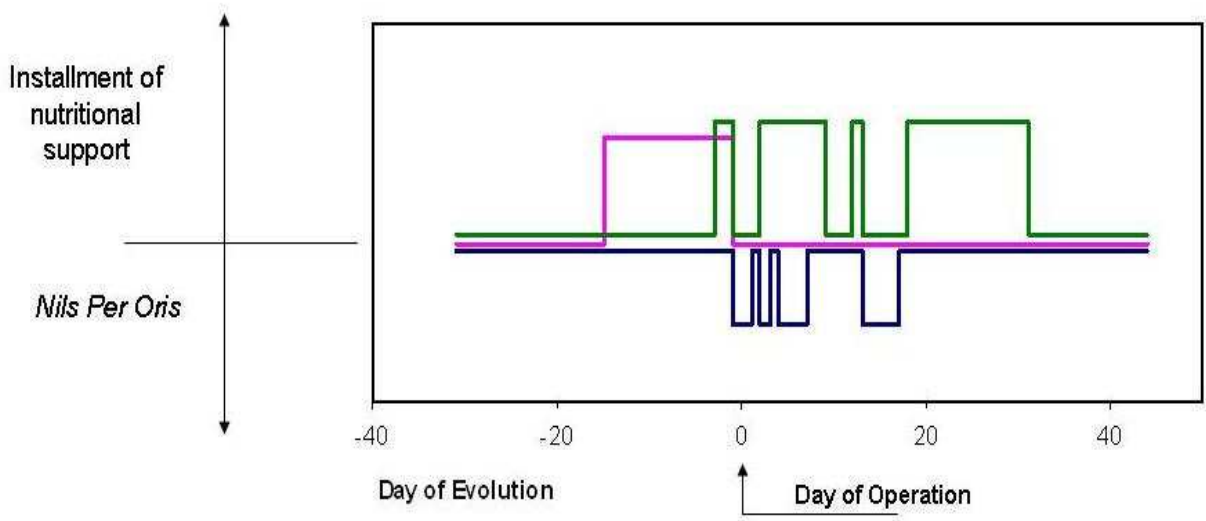

Oral Feedings — Volitional Enteral Nutrition ——Central Parenteral Nutrition

Fig. 5. Behavior of nutritional support during follow-up of the patient discussed in "Clinical case presentation" section. Discontinuities in the use of oral route are represented as falls of the solid blue line. Conduction of artificial nutritional schemes is symbolized as surges arising from the corresponding baseline. See text for further details. 


\section{Conclusions}

The results of a study model of metabolic response to stress conveyed by ESRV have been presented in this work. Body weight excess might become a predictor of post-surgical complications. This hypothesis will be reformulated in future works in order to explore if occurrence of complications after ESRV can be traced back to the different facets of Insulin resistance Syndrome associated to body weight excess, such as arterial hypertension, hyperglycemia, blood lipid disorders, and hyperuricemia, among others. It is expected that complications risk to be minimal among obese patients presenting with few stigmas of insulin resistance, but maximal in those exhibiting a critical number of such stigmas.

\section{Final notice}

The preceding discussion has focused on the link between nutrition and aortic aneurysm as an extreme form of aorto-iliac atherosclerotic disease, given the involvement of the author with the practice of a referral, tertiary Angiology Service. However, aortic aneurysm might result from other, atherosclerosis-independent causes. The case is presented of a teen-ager suffering from an aortic aneurysm of probable mycological origin being assisted at a medical surgical clinic in Havana City [50]. Size of aneurysm prevented oral feeding, thus causing a significant nutritional derangement. Central Parenteral nutrition using premixed, all-in-one admixtures (NutriFlex Lipid Peri, B|BRAUN, Melsungen, Germany) was started in order to sustain patient's nutritional status, and improve metabolic response to surgical trauma.

\section{Acknowledgements}

Dr. Fernando Vaquero Morillo, Director of ANGIOLOGIA, bimonthly journal of the Spanish Society of Angiology and Vascular Surgery, for his support and cooperation.

\section{References}

[1] Hirsch AT, Haskal ZJ, Hertzer NR, Bakal CW, Creager MA, Halperin JL, Hiratzka LF, Murphy WR, Olin JW, Puschett JB, Rosenfield KA, Sacks D, Stanley JC, Taylor LM Jr, White CJ, White J, White RA, Antman EM, Smith SC Jr, Adams CD, Anderson JL, Faxon DP, Fuster V, Gibbons RJ, Hunt SA, Jacobs AK, Nishimura R, Ornato JP, Page RL, Riegel B; American Association for Vascular Surgery; Society for Vascular Surgery; Society for Cardiovascular Angiography and Interventions; Society for Vascular Medicine and Biology; Society of Interventional Radiology; ACC/AHA Task Force on Practice Guidelines Writing Committee to Develop Guidelines for the Management of Patients With Peripheral Arterial Disease; American Association of Cardiovascular and Pulmonary Rehabilitation; National Heart, Lung, and Blood Institute; Society for Vascular Nursing; TransAtlantic Inter-Society Consensus; Vascular Disease Foundation. ACC/AHA 2005 Practice Guidelines for the management of patients with peripheral arterial disease (lower extremity, renal, mesenteric, and abdominal aortic): a collaborative report from the American Association for Vascular Surgery/Society for Vascular Surgery, Society for 
Cardiovascular Angiography and Interventions, Society for Vascular Medicine and Biology, Society of Interventional Radiology, and the ACC/AHA Task Force on Practice Guidelines (Writing Committee to Develop Guidelines for the Management of Patients With Peripheral Arterial Disease): endorsed by the American Association of Cardiovascular and Pulmonary Rehabilitation; National Heart, Lung, and Blood Institute; Society for Vascular Nursing; TransAtlantic InterSociety Consensus; and Vascular Disease Foundation. Circulation 2006;113:e463e654.

[2] Mariné ML, Valdés EF, Mertens MR, Krämer SchA, Bergoeing RM, Rivera DD, Vergara GJ, Carvajal NC. Open and endovascular surgery for the treatment of abdominal aortic aneurysm. Review of the available evidence. Rev Med Chil 2009;137:1081-8.

[3] Jaakkola P, Hippeläinen M, Oksala I. Infrarenal aortofemoral bypass surgery: risk factors and mortality in 330 patients with abdominal aortic aneurysm or aortoiliac occlusive disease. Ann Chir Gynaecol 1996;85(1):28-35.

[4] Fontaine R, Kolh P, Creemers E, Gerard P, Kerstenne MA, Van Damme H, Limet R. Open surgery for abdominal aortic aneurysm or aorto-iliac occlusive disease--clinical and ultrasonographic long-term results. Acta Chir Belg. 2008 Jul-Aug;108(4):393-9.

[5] Mullen JL, Gertner MH, Buzby GP, Goodhart GL, Rosato EF. Implication of malnutrition in the surgical patient. Arch Surg 1979;114:121-5.

[6] Windsor JA, Hill GL. Protein depletion and surgical risk. Aust NZ J Surg 1988;58:711-5.

[7] Sungurtekin H, Sungurtekin U, Balci C, Zencir M, Erdem E. The influence of nutritional status on complications after major intraabdominal surgery. J Am Coll Nutr 2004;23:227-32.

[8] Ortiz Reyes S, Aguilar Martínez F, Llanes Díaz G, González Díaz ME, González Villalonga JA, Santana Porbén S, Barreto Penie J. Valor predictivo de la encuesta subjetiva global en la conducta quirúrgica y la evolución posoperatoria del cancer colorrectal Revista Mexicana de Coloproctología 2005;11:114-22.

[9] Pacelli F, Bossola M, Rosa F, Tortorelli AP, Papa V, Doglietto GB. Is malnutrition still a risk factor of postoperative complications in gastric cancer surgery? Clin Nutr 2008;27:398-407.

[10] Anónimo. Etiology of atherosclerosis- special reference to humoral and neurogenic factors. Nippon Rinsho 2011;69:39-44.

[11] Hermus L, Lefrandt JD, Tio RA, Breek JC, Zeebregts CJ. Carotid plaque formation and serum biomarkers. Atherosclerosis 2010;213:21-9.

[12] Weingärtner $\mathrm{O}$, Lütjohann $\mathrm{D}$, Böhm M, Laufs U. Cholesterol homeostasis and cardiovascular risk. Dtsch Med Wochenschr 2011;136:34-8.

[13] Motoyama A, Saito R, Fujibayashi K, Aoki H, Kajinami K.Disorder in lipid metabolism. Nippon Rinsho 2010;68(Suppl 8):364-9.

[14] Ashburn DD, Reed MJ. Endocrine system and obesity. Crit Care Clin 2010;26:633-6.

[15] Gilardini L, Pasqualinotto L, Di Matteo S, Caffetto K, Croci M, Girola A, Invitti C. Factors associated with early atherosclerosis and arterial calcifications in young 
subjects with a benign phenotype of obesity. Obesity (Silver Spring). 27 de Enero del 2011. Epub ahead of print.

[16] García Lorda P. Role of lipid intake in obesity. Nutr Hosp 2002;17(Suppl 1):67-72.

[17] Astrup A. The role of dietary fat in obesity. Semin Vasc Med 2005;5:40-7.

[18] Gaesser GA. Carbohydrate quantity and quality in relation to body mass index. J Am Diet Assoc 2007;107:1768-80.

[19] Siri-Tarino PW, Sun Q, Hu FB, Krauss RM. Saturated fatty acids and risk of coronary heart disease: modulation by replacement nutrients. Curr Atheroscler Rep 2010;12:384-90.

[20] Glinsberg HN. Insulin resistance and its relation to coronary artery disease. J Clin Invest 2000;106:453-8.

[21] Tomkin GH. Atherosclerosis, diabetes and lipoproteins. Expert Rev Cardiovasc Ther 2010;8:1015-29.

[22] Wójkowska-Mach J, Bulanda M, Cencora A, Jawień A, Szczypta A, Rózańska A y cols. Surgical site infections following vascular surgery. Przegl Epidemiol 2007;61: 683-91.

[23] Dempsey DT, Mullen JL, Buzby GP. The link between nutritional status and clinical outcome: can nutritional intervention modify it? Am J Clin Nutr 1988;47: 352-6.

[24] Kavalukas SL, Barbul A. Nutrition and wound healing: an update. Plast Reconstr Surg 2011;127 (Suppl 1):38S-43S.

[25] García Lizame ML, Eliseo Mussenden O, Peguero Brínguez Y, Díaz Hernández O, Santana Porbén S. Influencia del estado nutricional en los resultados de la cirugía revascularizadora del sector aortoilíaco. Angiología [España] 2009;61:315-24.

[26] Kotler DP, Tierney AR, Wang J, Pierson RN Jr. Magnitude of body-cell-mass depletion and the timing of death from wasting in AIDS. Am J Clin Nutr 1989;50:444-7.

[27] Harris CL, Fraser C. Malnutrition in the institutionalized elderly: the effects on wound healing. Ostomy Wound Manage 2004;50:54-63.

[28] Esposito S. Immune system and surgical site infection. J Chemother 2001;13 Spec No 1: 12-6.

[29] Barchfeld T, Schönhofer B. Difficult weaning. Pneumologie 2006;60:616-28.

[30] Stratton RJ, Marinos E. Who benefits from nutritional support: what is the evidence? Eur J Gastroenterol Hepatol 2007;19:353-8.

[31] Mowery NT, May AK, Collier BC, Dossett LA, Gunter OL, Dortch MJ, Diaz JJ Jr. Glucose metabolism, not obesity, predicts mortality in critically ill surgical patients. Am Surg 2010;76:1377-83.

[32] Santana Porbén S, Barreto Penié J. Metabolismo de los sustratos. En: Manual de Nutrición Enteral y Parenteral (Editores: Arenas Márquez H, Anaya Prado R). Editorial Interamericana McGraw-Hill. Ciudad México: 2007. pp 23

[33] Rosen ED, Spiegelman BM. Adipocytes as regulators of energy balance and glucose homeostasis. Nature 2006;444:847-53. 
[34] Mullen JT, Moorman DW, Davenport DL. The obesity paradox: body mass index and outcomes in patients undergoing nonbariatric general surgery. Ann Surg 2009;250:166-72.

[35] Kuk JL, Saunders TJ, Davidson LE, Ross R. Age-related changes in total and regional fat distribution. Ageing Res Rev 2009;8:339-48.

[36] Lerman Garber I, Rosales Calderón M. Changes in glucose tolerance in elderly. Rev Invest Clin 2010;62:312-7.

[37] Chapkin RS, Kim W, Lupton JR, McMurray DN. Dietary docosahexaenoic and eicosapentaenoic acid: emerging mediators of inflammation. Prostaglandins Leukot Essent Fatty Acids 2009;81:187-91.

[38] Saremi A, Arora R. The utility of omega-3 fatty acids in cardiovascular disease. Am J Ther 2009;16:421-36.

[39] Cawood AL, Ding R, Napper FL, Young RH, Williams JA, Ward MJ, Gudmundsen O, Vige R, Payne SP, Ye S, Shearman CP, Gallagher PJ, Grimble RF, Calder PC. Eicosapentaenoic acid (EPA) from highly concentrated n-3 fatty acid ethyl esters is incorporated into advanced atherosclerotic plaques and higher plaque EPA is associated with decreased plaque inflammation and increased stability. Atherosclerosis 2010;212:252-9.

[40] Berger MM, Tappy L, Revelly JP, Koletzko BV, Gepert J, Corpataux JM, Cayeux MC, Chiolero RL. Fish oil after abdominal aorta aneurysm surgery. Eur J Clin Nutr $2008 ; 62: 1116-22$.

[41] Balk EM, Lichtenstein AH, Chung M, Kupelnick B, Chew P, Lau J. Effects of omega-3 fatty acids on serum markers of cardiovascular disease risk: a systematic review. Atherosclerosis 2006;189:19-30.

[42] Gaesser GA. Carbohydrate quantity and quality in relation to body mass index. J Am Diet Assoc 2007;107:1768-80.

[43] Linde JA, Utter J, Jeffery RW, Sherwood NE, Pronk NP, Boyle RG. Specific food intake, fat and fiber intake, and behavioral correlates of BMI among overweight and obese members of a managed care organization. Int J Behav Nutr Phys Act 2006;3:42.

[44] Liese AD, Roach AK, Sparks KC, Marquart L, D'Agostino RB Jr, Mayer-Davis EJ. Whole-grain intake and insulin sensitivity: the Insulin Resistance Atherosclerosis Study. Am J Clin Nutr 2003;78:965-71.

[45] Li SC, Liu YH, Liu JF, Chang WH, Chen CM, Chen CY. Almond consumption improved glycemic control and lipid profiles in patients with type 2 diabetes mellitus. Metabolism 2011;60:474-9.

[46] Estruch R, Martínez-González MA, Corella D, Basora-Gallisá J, Ruiz-Gutiérrez V, Covas MI, Fiol M, Gómez-Gracia E, López-Sabater MC, Escoda R, Pena MA, Diez-Espino J, Lahoz C, Lapetra J, Sáez G, Ros E; PREDIMED Study Investigators. Effects of dietary fibre intake on risk factors for cardiovascular disease in subjects at high risk. J Epidemiol Community Health 2009; 63:582-8.

[47] Georgieff M, Moldawer LL, Bistrian BR, Blackburn GL. Xylitol, an energy source for intravenous nutrition after trauma. JPEN J Parenter Enter Nutr 1985;9:199-209. 
[48] Sun LC, Shih YL, Lu CY, Chen FM, Hsieh JS, Chuang JF, Wang JY. Randomized controlled study of glycerol versus dextrose in postoperative hypocaloric peripheral parenteral nutrition. J Invest Surg 2006;19:381-5.

[49] Haglund U. The splanchnic organs as the sources of toxic mediators in shock. Prog Clin Biol Res 1988;264:135-45.

[50] Alvarez Rodríguez A. Soporte Nutricional en un caso de aneurisma aorto-abdominal. Uso de los lípidos parenterales. RCAN Rev Cubana Aliment Nutr 2010;20:S17-S20. Available at:

http://www.revicubalimentanut.sld.cu/Vol_20_1/SimposioLipidosNutricionArtif icial.pdf. Last visited on: Wednesday, June 01, 2011. 


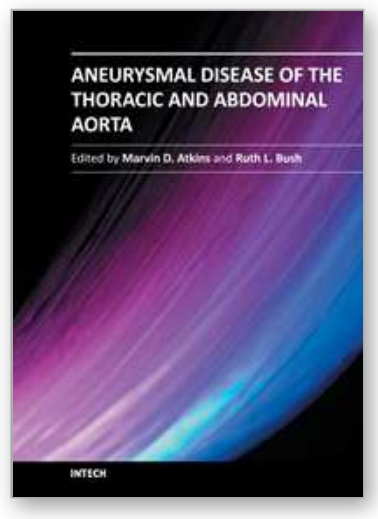

\author{
Aneurysmal Disease of the Thoracic and Abdominal Aorta \\ Edited by Dr. Ruth Bush
}

ISBN 978-953-307-578-5

Hard cover, 226 pages

Publisher InTech

Published online 16, December, 2011

Published in print edition December, 2011

The first successful open surgical repair of an abdominal aortic aneurysm was in 1951 by Dubost and represented a tremendous milestone in the care of this challenging disease. The introduction of endovascular repair in 1991 by Parodi furthered the care of these patients by allowing for lower morbidity and mortality rates and also, enabling surgeons to extend surgical treatment to patients traditionally deemed too high of a surgical risk. This new book on Aortic Disease covers many interesting and vital topics necessary for both the practicing surgeon as well as a student of vascular disease. The book starts with background information on the evolution of aortic management from traditional open surgical repair to modern endovascular therapies. There is also a chapter covering the data supporting current treatment modalities and how these data have supported modern management. Also, the use of endovascular means for care of the challenging situation of ruptured aneurysms is discussed. In addition to management of abdominal aneurysm, there is a chapter on treatment of aneurysms of the ascending aorta. Along with surgical treatment, one must also understand the molecular basis for how blood vessels remodel and thus, the role of cathepsins in aortic disease is elucidated. Lastly, chapters discussing the perioperative management of radiation exposure and ultrasound-guided nerve blocks as well as the need for high-quality postoperative nutrition will lend well to a full understanding of how to management patients from presentation to hospital discharge. We hope you enjoy this book, its variety of topics, and gain a fuller knowledge of Aneurysmal Disease of the Thoracic and Abdominal Aorta.

\title{
How to reference
}

In order to correctly reference this scholarly work, feel free to copy and paste the following:

Sergio Santana Porbén (2011). Nutrition and the Aorto-lliac Atherosclerotic Disease, Aneurysmal Disease of the Thoracic and Abdominal Aorta, Dr. Ruth Bush (Ed.), ISBN: 978-953-307-578-5, InTech, Available from: http://www.intechopen.com/books/aneurysmal-disease-of-the-thoracic-and-abdominal-aorta/nutrition-and-theaorto-iliac-atherosclerotic-disease

\section{INTECH}

open science | open minds

\section{InTech Europe}

University Campus STeP Ri

Slavka Krautzeka 83/A

51000 Rijeka, Croatia

Phone: +385 (51) 770447

\section{InTech China}

Unit 405, Office Block, Hotel Equatorial Shanghai

No.65, Yan An Road (West), Shanghai, 200040, China

中国上海市延安西路65号上海国际贵都大饭店办公楼 405 单元

Phone: +86-21-62489820 
Fax: +385 (51) 686166

Fax: +86-21-62489821

www.intechopen.com 
(C) 2011 The Author(s). Licensee IntechOpen. This is an open access article distributed under the terms of the Creative Commons Attribution 3.0 License, which permits unrestricted use, distribution, and reproduction in any medium, provided the original work is properly cited. 